BBA 55452

\title{
PROPERTIES OF CEREBROSIDE GALACTOSIDASE
}

\author{
DAVID M. BOWEN* AND NORMAN S. RADIN \\ Mental Health Research Institute, University of Michigan, Ann Arbor, Mich. 48104 (U.S.A.) \\ (Received December Ist, I967) \\ (Revised manuscript received February 2nd, I968)
}

SUMMARY

Rat brain cerebrosidase was shown by centrifugal fractionation to be a lysosomal enzyme. The $\mathrm{pH}$ optimum was found to be 4.5 . Taurocholate greatly stimulated its action. The addition of palmitic acid had little effect on the enzyme activity, but ceramide, sphingosine, and ceramide lactoside inhibited. Galactose, galactonolactone, and galactitol inhibited the enzyme, but the corresponding compounds with the glucose configuration did not. From this it may be concluded that the enzyme is active only toward galactosides, rather than glucosides. However, the enzyme preparation was able to hydrolyze ceramide glucoside, evidently because a second enzyme was present. The preparation was also active toward ceramide and ceramide lactoside, but rather inert toward galactosylgalactosylglucosyl ceramide. The molecular weight, determined by gel chromatography, was about 50000 .

The cerebrosidase occurring in the supernatant fluid of brain homogenates was shown by Sephadex chromatography to be associated with material of high molecular weight. The enzyme could be partially dissociated by addition of cholate plus Triton $\mathrm{X}$-IOo. The crude cerebrosidase that was extractable from brain particles also showed associated and dissociated forms.

\section{INTRODUCTION}

The purification of a galactosidase which acts on ceramide galactosides was described in the accompanying paper ${ }^{1}$. The cerebrosidase was obtained in soluble form from rat brain particles that sedimented between $\mathrm{I} 000$ and $13000 \times \mathrm{g}$. This communication describes properties of the preparation and contrasts it with other glycosidases, particularly those active toward glycolipids.

\section{MATERIALS AND METHODS}

\section{Enzymes}

Most of this work was carried out with cerebrosidase that was purified by a

\footnotetext{
* Postdoctoral trainee, National Institute of Mental Health, Behavioral Sciences Training Branch.
} 
combination of electrophoresis and ion-exchange chromatography (Enzyme I). Its sperifir activity, measured with I 8 : o cerebroside, was $0.159 \mu$ moles $/ \mathrm{h}$ per mg protein. The other preparation used was purified similarly but without electrophoresis (Enzyme 2). It had a specific activity, toward mixed ${ }^{3} \mathrm{H}$-labeled cerebrosides, of 0.084 $\mu$ moles/h per mg. Enzyme assays were carried out by measuring the amount of radioactive galactose released.

Aryl sulfatase A activity was measured at $\mathrm{pH} 5$ using 2-hydroxy-5-nitrophenyl sulfate (Sigma Chemical Co., St. Louis, Mo.) ${ }^{2}$. N-Acetylglucosaminidase was assayed at $\mathrm{pH} 5$ with the nitrophenyl glycoside as substrate ${ }^{3}$.

\section{Reagents}

Silica gel columns were packed with Unisil, Clarkson Chemical Co., Williamsport, Pa. and silica gel thin-layer plates were made with Silica Gel G, Brinkmann Instruments, Westbury, N.Y. Alumina was grade I, basic, from Woelm-Eschwege, Germany:

Gifts of lipids were obtained from Dr. Ruscoe BRADY (synthetic 16:0 ceramide lactoside) and Dr. Charles SweEley (ceramide trihexoside, galactosylgalactosylglucosyl ceramide). Ceramide glucoside was isolated from Gaucher spleens ${ }^{4,5}$. Psychosine (galactosyl sphingosine) was made by Dr. Milada Dobiasova in this laboratory by a modification of the method of TAKETOMI AND YAMAKAWA ${ }^{6}$. Sphingosine was made from beef brain sphingolipids ${ }^{7}$ and mixed cerebrosides were used to prepare mixed ceramides $^{8}$, which were purified by silica gel chromatography. Stearate-labeled ceramide was prepared previously ${ }^{9}$.

$\gamma$-D-Galactonolactone was obtained from Mann Research Labs., New York.

\section{RESLLTS}

\section{Subcellular localization}

In the preceding paper ${ }^{1}$, it was shown that cerebrosidase is concentrated in brain particles sedimenting between $\mathrm{I} 000$ and $\mathrm{I} 3000 \times \mathrm{g}$. The low optimal $\mathrm{pH}$ of this hydrolase suggested that it is localized in the lysosomes. In a test of this possibility, a lysosomal concentrate and other fractions were prepared by centrifugation schedule

\section{TABLE I}

SUBCELLULAR LOCALIZATION OF CEREBROSIDE GALACTOSIDASE

Subcellular fractions were prepared from the cortex of two I $50 \mathrm{~g}$ male rats. Cerebroside galactosidase was measured using the mixture of labeled cerebrosides. Incubation conditions: $0.5 \mathrm{ml} \mathrm{en}-$ zyme in $0.125 \mathrm{M}$ sucrose $+0.4 \mathrm{ml}$ substrate emulsion +o.I ml I M sodium citrate $\left(\mathrm{pH}_{4.5}\right) ; 37^{\circ}$ for $3 \mathrm{~h}$. The emulsion contained o. I mg labeled cerebroside $+\mathrm{I} \mathrm{mg}$ Tween $20+0.5 \mathrm{mg} \mathrm{G}-2 \mathrm{I} 59+4 \mathrm{mg}$ sodium taurocholate.

\begin{tabular}{|c|c|c|c|c|c|c|}
\hline Enzyme & \multicolumn{6}{|c|}{ Relative specific concentration* } \\
\hline $\begin{array}{l}\text { Subcellular } \\
\text { fraction }\end{array}$ & $\begin{array}{l}\text { Nuclei } \\
\text { and debris }\end{array}$ & $\begin{array}{l}\text { Mito- } \\
\text { chondria }\end{array}$ & $\begin{array}{l}\text { Lyso- } \\
\text { somes }\end{array}$ & $\begin{array}{l}\text { Micro- } \\
\text { somes }\end{array}$ & $\begin{array}{l}\text { Super- } \\
\text { natant }\end{array}$ & $\begin{array}{l}\text { Ratio mitochon- } \\
\text { dria/lysosomes }\end{array}$ \\
\hline Galactosidase & 0.64 & $\mathrm{I} .68$ & 3.84 & 0.56 & 0.32 & 0.44 \\
\hline Aryl sulfatase & 0.75 & 2.00 & 3.12 & $0.5^{8}$ & 0.15 & 0.64 \\
\hline Glucosa minidase & 0.85 & I. 42 & 2,42 & 0.79 & 0.56 & 0.59 \\
\hline Protein $\left({ }_{1}^{\circ}\right.$ of total $)$ & $17 \cdot I$ & $23 \cdot 4$ & 7.0 & 25.0 & $27 \cdot 4$ & \\
\hline
\end{tabular}

* $\%$ of total activity $/ \%$ of total protein.

Biochim. Biophys. Acta, I 52 (1968) 599-610 
A of Sellinger and De Balbian Verster ${ }^{10}$. Assay of these fractions (Table I) showed cerebrosidase to be strongly concentrated in the lysosomal fraction. A similar result was obtained for the typical cerebral lysosomal enzymes, aryl sulfatase $A$ (ref. 2) and acetylglucosaminidase ${ }^{3}$. Compared with the lysosomal fraction, the relative specific concentration of cercbrosidase in the mitochondrial fraction was misleadingly low (Table I). This is due to the presence of endogenous cerebrosides in the mitochondrial fraction, which includes myelin. The linearity in the relation, activity 's. enzyme amount, was excellent in the lysosomal fraction, indicating a low level or absence of cerebroside in these particles.

When labeled cerebrosides and o-nitrophenyl galactoside were compared similarly, using fractions enriched in myelin, nerve endings, and mitochondria ${ }^{11}$, a marked similarity in hydrolase distribution was observed. Since activity toward the unnatural substrate appears to be localized in cerebral lysosomes ${ }^{12}$, this experiment gives additional support for the belief that cerebrosidase is a lysosomal enzyme.

\section{Properties of the hydrolytic reaction}

The $\mathrm{pH}$ optimum of the cerebrosidase (prepared in the same way as Enzyme 2) was the same, $\mathrm{pH} 4.5$, as previously determined for the cerebrosidase obtained from the supernatant fluid from pig-brain homogenate. The time course of the reaction was linear for at least $4 \mathrm{~h}$ and the observed activity was directly proportional to weight of enzyme (up to at least $40 \mu \mathrm{g}$ of Enzyme $\mathrm{I}$ ).

Taurocholate was very highly stimulatory, as found also with the cerebrosidase from the supernatant fluid. Omission of this bile salt reduced activity by $99 \%$. The optimal concentration was about $1.5 \mathrm{mg} / \mathrm{ml}$ but even $8 \mathrm{mg} / \mathrm{ml}$ was not much lcss effective. The stimulatory effect of the other detergents was somewhat less. In earlier experiments Triton $\mathrm{X}$-Ioo produced an enhancement of about $\mathrm{I} / 3$, but in later experiments (with purer enzyme) it was actually slightly inhibitory.

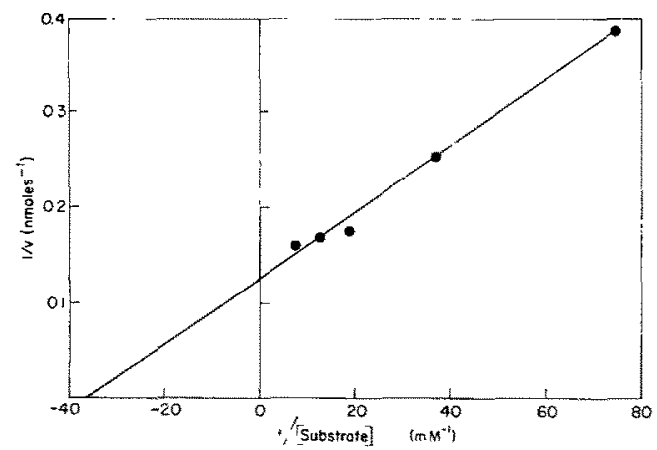

Fig. I. Effect of substrate concentration. Chloroform-methanol solutions of $18: 0$ cerebroside with

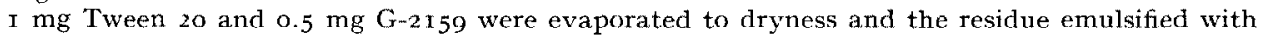
$0.5 \mathrm{ml}$ of taurocholate solution $(3.75 \mathrm{mg} / \mathrm{ml})$. The results were obtained with $35.3 \mu \mathrm{g}$ of Enzyme I after a $2 \mathrm{~h}$ incubation period.

Enzyme $\mathrm{x}$ exhibited a $K_{m}$ with $18: 0$ cerebroside of $27 \mu \mathrm{M}$ (Fig. I). This is very close to the value found for the rat brain galactosidase acting on ceramide lactoside ${ }^{13}$. The $v_{\max }$, calculated from the intercept, was $0.23 \mu$ moles/h per mg protein. Substrate concentrations higher than those shown in Fig. I yielded turbid emulsions which gave unrealistically low activities. 


\section{Effects of added lipids}

GATT ${ }^{14}$ has compared four sphingolipid-cleaving enzymes with respect to the effect of adding sphingosine, palmitate, or $N$-palmitoyl sphingosine. A similar comparison with cerebrosidase is shown in Table II. It can be seen that sphingosine is a failly effective inluibitor, while ceramide, the product of cerebrosidase actiun, is less so (Expt. I). As our enzyme preparation contained ceramidase activity ${ }^{1}$, it seemed possible that sphingosine was formed during the incubation and that the inhibitory effect of ceramide was the result of sphingosine formation. Since GATT reported ${ }^{15}$ (and we confirmed) that ceramidase is inhibited by palmitic acid, we examined the effect of the acid on our enzyme with and without added ceramide (Table II, Expt. 2).

TABLE II

\section{EFFECT OF ADDED LIPIDS ON HYDROLYSIS OF STEAROYL CEREBROSIDE}

Incubation as in Table I but enzymes were in Buffer A (ref. I) and taurocholate was reduced to I.5 mg. Expt. I : The inhibitors were evaporated to dryness from solution in the incubation tubes and emulsified in the substrate emulsion. Expts. 2 and 3: The inhibitors were evaporated together with the cerebroside and the two were emulsified together.

\begin{tabular}{|c|c|c|c|}
\hline Expt. & $\begin{array}{l}\text { Added } \\
\text { lipid }\end{array}$ & $\begin{array}{l}\text { umoles of } \\
\text { lipid }\end{array}$ & $\begin{array}{l}\text { \% of control } \\
\text { activity* }\end{array}$ \\
\hline $\mathbf{I}: 27.5 \mu \mathrm{g}$ of Enzyme I & $\begin{array}{l}\text { Sphingosine } \\
\text { Sphingosine } \\
\text { Sphingosine } \\
\text { Ceramide (mixed) } \\
\text { Ceramide (mixed) }\end{array}$ & $\begin{array}{l}0.5 \\
I \\
2 \\
2 \\
8\end{array}$ & $\begin{array}{l}55 \\
33 \\
13 \\
58 \\
35\end{array}$ \\
\hline $2:$ I $8.5 \mu \mathrm{g}$ of Enzyme I & $\begin{array}{l}\text { Ceramide (mixed) } \\
\text { Palmitic acid } \\
\text { Ceramide }+ \text { palmitic acid }\end{array}$ & $\begin{array}{l}2 \\
4 \\
2+4\end{array}$ & $\begin{array}{l}3 \mathbf{r} \\
94 \\
33\end{array}$ \\
\hline $3: 39.0 \mu \mathrm{g}$ of Enzyme $\mathrm{I}^{* *}$ & $\begin{array}{l}\text { Ceramide lactoside } \\
\text { Ceramide trihexoside } \\
\text { Ceramide }(\mathrm{I} 8 ; \mathrm{o})\end{array}$ & $\begin{array}{l}0.065 \\
0.065 \\
0.065\end{array}$ & $\begin{array}{l}72 \\
91 \\
93\end{array}$ \\
\hline
\end{tabular}

* Activity in absence of inhibitor is $100 \%$.

** Fxpt. 3 carried out with half the usual amonnt of cerebroside.

The fatty acid alone did not appreciably inhibit cerebroside cleavage, and the inhibitory effect of ceramide was not reversed. In experiments with less purified enzyme we found that $4 \mathrm{mM}$ palmitic acid (emulsified as in Expt. I, with $4 \mathrm{mg}$ taurocholate and I.I $\mathrm{mg}$ Triton in addition to the other detergents) stimulated hydrolysis by $27 \%$. In Expt. 3 , in which the amount of added lipid equalled the amount of substrate, slight inhibitory effects were observed with ceramide and trihexoside, but ceramide dihexoside produced an appreciable inhibition.

\section{Effects of added carbohydrates}

Table III shows the results of adding glucose, galactose, and compounds of related configurations. Galactonolactone was the most potent inhibitor and gluconolactone was almost inactive. As observed previously with the cerebrosidase from brain supernatant ${ }^{4}$, nitrophenyl galactoside proved to be inhibitory, but only at a relatively high concentration (nitrophenyl galactoside/cerebroside $=250$ ). Galactose, but not glucose, was moderately inhibitory and a similar relation was observed with the corresponding hexitols. Erythritol, which preferentially inhibits glucosidase ${ }^{16}$, had only a slight effect on the cerebrosidase. Lactose inhibited only slightly. 
Additional experiments showed that glycerol, in relatively high concentration $(7.5 \%)$, inhibited $38 \%$ while hyaluronic acid $(0.2 \mathrm{mg} / \mathrm{ml})$ had no effect. This acid mucopolysaccharide had previously been shown to inhibit ram testis $\beta$-galactosidase ${ }^{17}$. Two antibiotics, lincomycin ${ }^{18}$ and celesticetin salicylate ${ }^{19}$, were tested because of their appreciable resemblance to ceramide galactoside. Both contain a carbohydrate moiety whose ring structure is that of galactose, and an adjacent amide group; however, the $\mathrm{C}$-I position of the sugar is bound in an $\alpha$-thioglycosidic linkage. The lincomycin, at $22 \mathrm{mM}$ concentration, had no effect, but the celesticetin, at $18 \mathrm{mM}$, produced an inhibition of $44 \%$. The latter is thus about as inhibitory as nitrophenyl galactoside. (Part of the inhibitory effect is due to the salicylic acid portion.)

The water-soluble cerebrosidase described in Table III was compared with the enzyme in the insoluble portion remaining from lipase action. The insoluble material in this experiment contained $\mathrm{r} / 2$ the activity found in the soluble portion. On extraction with Buffer B (ref. I) containing $0.04 \%$ Triton X-Ioo, very little activity came into solution. Repetition of the extraction, but with $0.2 \%$ Triton, brought about I/3 of the activity into solution. The preparation (Triton-soluble enzyme) had a specific

\section{TABLE III}

EFFECT OF CARBOHYDRATES ON HYDROLYSIS

Incubation conditions as in Table I but Buffer A (ref. I) was used instead of sucrose and Triton was added to give a total of I.I $\mathrm{mg}$ in each tube. Water soluble enzyme was $53 \mu \mathrm{g}$ of Enzyme 2 . The preparation of the Triton soluble enzyme $(37 \mu \mathrm{g} /$ tube) is described in the text.

\begin{tabular}{|c|c|c|c|}
\hline \multirow[t]{2}{*}{ Addition } & \multirow{2}{*}{$\begin{array}{l}\text { Concn. } \\
(m M)\end{array}$} & \multicolumn{2}{|l|}{ \% of control activity* } \\
\hline & & Water soluble enzyme & Triton soluble enzyme \\
\hline$\gamma$-D-Galactonolactone & 0.8 & I I & Io \\
\hline$\delta$-D-Gluconolactone & 0.8 & 97 & IOO \\
\hline$o$-Nitrophenyl galactoside & 30 & 38 & 36 \\
\hline Galactose & 60 & 67 & 70 \\
\hline Glucose & 60 & 96 & $\mathrm{IO}_{4}$ \\
\hline Lactose & 60 & 90 & 95 \\
\hline Dulcitol & IOO & 80 & 80 \\
\hline Sorbitol & 100 & 95 & 99 \\
\hline Erythritol & 100 & 86 & 103 \\
\hline
\end{tabular}

* Activity in absence of carbohydrates is $100 \%$.

activity of $0.057 \mu$ moles mixed cerebroside hydrolyzed per $h$ per mg protein. The effects of various carbohydrates on this preparation are shown in the right side of Table III. It is apparent that the two cerebrosidase preparations are very similar in sensitivity to specific inhibitors. Both were found to exhibit the same $\mathrm{pH}$ optimum. From these results it would appear that the Triton-solubilized enzyme differed from the lipase-solubilized enzyme only in the nature of the materials to which they had been bound.

\section{Substrate specificity}

The activity of the cerebrosidase (Enzyme I) toward various glycolipids was evaluated by isolating and determining the lipoidal products. The problem of removing the detergents was solved by chromatography with alumina and alkaline methanolysis (which cleaves the ester-type detergents). Incubation was carried out in the usual manner but with the addition of $4 \mu$ moles of palmitic acid to minimize hydrolysis of any ceramide that might be formed. 
After incubation for $5 \mathrm{~h}, 0.2 \mathrm{ml}$ of I $\mathrm{M} \mathrm{NaOH}$ were added, followed by $5 \mathrm{ml}$ of chloroform-methanol $(2: \mathrm{I}, \mathrm{v} / \mathrm{v}) \mathrm{mixing}$, and centrifugation. The lower layer was washed twice with 3 -ml portions of "FoLCH upper layer" containing $0.05 \mathrm{M} \mathrm{KCl}$ and once without the $\mathrm{KCl}$. The lipids of the lower layer were fractionated with a column of Unisil ( $0.6 \mathrm{~g}, 4 \mathrm{~mm}$ internal diameter) packed in chloroform-methanol (98:2, $\mathrm{v} / \mathrm{v})$. Elution with $\mathrm{I} 5 \mathrm{ml}$ of chloroform-methanol $(98: 2, \mathrm{v} / \mathrm{v})$ yielded the ceramide fraction, chloroform-methanol $(94: 6, \mathrm{v} / \mathrm{v})$ yielded the cerebroside fraction, and chloroform-methanol $(80: 20, \mathrm{v} / \mathrm{v})$ yielded sphingosine and ceramide lactoside. The ceramide fraction was purified further with a column containing $\mathrm{I} g$ of alumina. Elution with $23 \mathrm{ml}$ of chloroform yielded detergent and chloroform-methanol $(95: 5, \mathrm{v} / \mathrm{v})$ yielded ceramide. The ceramide was subjected to alkaline methanolysis, thin-layer chromatography ${ }^{9}$, and acid methanolysis in O-ring test tubes ${ }^{21}$. The resultant fatty esters were analyzed by gas--liquid chromatography with a Kovar seal column². Quantitation was by means of an internal standard, 2 I:0.

The glycolipids were identified by thin-layer chromatography, the spots being visualized with a Bial reagent. In the case of the dihexoside, alkaline methanolysis was carried out prior to thin-layer chromatography. The sphingosine fraction was also subjected to alkaline methanolysis, extracted at alkaline $\mathrm{pH}$, and examined by thinlayer chromatography ${ }^{23}$.

In one experiment, I03 $\mu$ g of Enzyme I (purified by $\mathrm{pH} 5$ precipitation ${ }^{1}$ ) were incubated with galactose-labeled I 8: o cerebroside. The radioactivity in the aqueous layer (subsequent to reduction of the $\mathrm{pH}$ to 6.5 ) showed that 60.4 nmoles of galactose had been released. Analysis of the ceramide fraction showed that I8:0 was the only acid present and that 58.4 nmoles of ceramide had been formed. A trace of sphingosine was also detected. In another experiment, with $125 \mu \mathrm{g}$ of Enzyme I, 73.3 nmoles of galactose and 64.I nmoles of ceramide were formed.

From these results it may be seen that reasonable stoichiometry was obtained, and that ceramidase activity was not significant.It is also evident that the ceramide was formed by direct hydrolysis of the glycosidic bond rather than by fatty acid release, hydrolysis of the psychosine, and synthesis of ceramide from sphingosine and fatty acid. If the latter series of steps had occurred, the ceramide would have contained much palmitate ${ }^{15}$.

Table IV shows the results of the incubations with various glycolipids. Line I reveals that Enzyme I was somewhat less active toward ceramide glucoside than toward the corresponding galactoside. The former lipid contained very long chain fatty acids as the major component and one might expect that the difference in reactivity was due to slower attack on the long chain cerebrosides. However, comparison of the fatty acid distribution in substrate glucoside and resultant ceramide showed no important difference. This was shown also with the enzyme prepared from the brain supernatant fluid ${ }^{4}$.

Purification of Enzyme I by acid precipitation ${ }^{1}$ (Line 8 ) selectively reduced the activity toward ceramide glucoside. This is consistent with the observation with rat brain $^{\mathbf{2 4}}$ that nitrophenyl glucosidase is precipitated at $\mathrm{pH} \mathbf{5}$.

Ceramide lactoside (Table IV, Line 2) yielded ceramide (25.6 nmoles) and an appreciable amount of material identified by thin-layer chromatography as ceramide glucoside. The relative overall activity toward the lactoside shown in Table IV was estimated from the intensity of the lactoside spot observed after incubation with and 


\section{TABLE IV}

SPECIFICITY OF ENZYME

A solution containing o. I mg of sphingolipid, I mg palmitic acid, $1.1 \mathrm{mg}$ Triton, I mg Tween, and $0.5 \mathrm{mg}$ G-2159 was evaporated to dryness in the incubation tube, then taken up in $0.2 \mathrm{ml}$ taurocholate solution $(20 \mathrm{mg} / \mathrm{ml})$. For assay of the nitrophenyl glycosides ${ }^{4}$ the above detergents were taken up in the taurocholate solution containing $5 \mu$ molcs of each glycoside. Enzymes (u. / Inl) were in a mixture of Buffer A (ref. I) and water $(5: 2, v / v)$. Citrate buffer was added as usual and the incubation time was $5 \mathrm{~h}$. During this period Enzyme I (125 $\mu \mathrm{g}$ ), pH-5 supernatant (103 $\mu \mathrm{g}$ ), and the $\mathrm{pH}-4.5$ precipitate (obtained from $97 \mu \mathrm{g}$ of Enzyme $\mathrm{I}$ ) were found to hydrolyze 73,60 , and 30 nmoles respectively of $18: 0$ ceramide $\left[{ }^{3} \mathrm{H}\right]$ galactoside. These are the control values used in calculating the relative activities toward the other substrates.

\begin{tabular}{|c|c|c|}
\hline Substrate & Enzyme & $\begin{array}{l}\text { :o of control } \\
\text { activity }\end{array}$ \\
\hline 1. Ceramide glucoside & I & 40 \\
\hline 2. Ceramide lactoside & $\mathbf{I}$ & 100 \\
\hline 3. Ceramide trihexoside & $\mathbf{I}$ & ro \\
\hline 4. 0 -Nitrophenyl galactoside & $\mathbf{I}$ & 500 \\
\hline 5. o-Nitrophenyl galactoside & $\mathbf{I}$ & 1100 \\
\hline 6. $p$-Nitrophenyl glucoside & I & 66 \\
\hline 7. $p$-Nitrophenyl glucoside* & 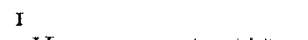 & 15 \\
\hline 8. Ceramide glucoside & pH-5 supernatant** & 25 \\
\hline 9. Ceramide lactoside & pH-4.5 precipitate*** & 100 \\
\hline xo. o-Nitrophenyl galactoside* & $\mathrm{pH}-1.5$ precipitate $* * *$ & $2 \mathrm{I}+$ \\
\hline
\end{tabular}

* Detergent omitted from the incubation tubes.

* Prepared from Enzyme I (ref. 1).

*** Enxyme I (in a mixture of buffer, glyreml, and $0.3^{\circ}:$ taurocholate) rvas dialyzed against 0.05 M citrate buffer containing $I^{\circ} ;$ galactose and $0.15^{\circ} \circ$ taurocholate $(\mathrm{pH} 4.5)$. Centrifugation at $100000 \times g$ for $\mathrm{I} h \mathrm{yielded}$ a supernatant that was inactive toward cerebroside. The active precipitate was suspended in $0.05 \mathrm{M}$ citrate ( $\mathrm{pH} 5.3$ ), containing $\mathrm{I}_{0}^{0}$ galactose, stored overnight, and the inactive supernatant liquid discarded.

without enzyme. As shown in Line 9, an acid precipitation step in the presence of taurocholate did not effect a separation of the galactosidase activities toward monoand dihexosides.

When ceramide trihexoside was tested, very little hydrolysis was observed (Line 3). The only detectable lipoidal product was ceramide, whose fatty acid composition agreed satisfactorily with that of the substrate ${ }^{25}$.

A small amount of psychosine was also hydrolyzed by Enzyme I, as shown by production of sphingosine. An intestinal preparation active toward ceramide glucoside and galactoside was also reported to have similar slight activity toward psychosine ${ }^{26}$. Except for the incubation with i 8: o cerebroside, only a barest trace or no sphingosine was found in the hydrolysates from the other sphingolipids.

The amount of hydrolysis of the nitrophenyl glycosides (Lines 4-7) was affected by the presence of detergents. Galactoside cleavage was considerably inhibited by detergents, while glucoside cleavage was stimulated.

Comparison of Lines 5 and ro shows that it is possible to improve the removal of nitrophenyl galactosidase activity from cerebrosidase.

\section{Molecular weight}

Following the method of ANDREws ${ }^{27}$, a column of Sephadex G-200 was standardized with several proteins of known molecular weight, and a sample of Enzyme $I$ was then passed through the same column. Blue Dextran and cytochrome $c$ were added to the enzyme as internal standards. Fig. 2 shows the elution data by which the cerebrosidase was calculated to have a molecular weight of roughly 50ooo. This 


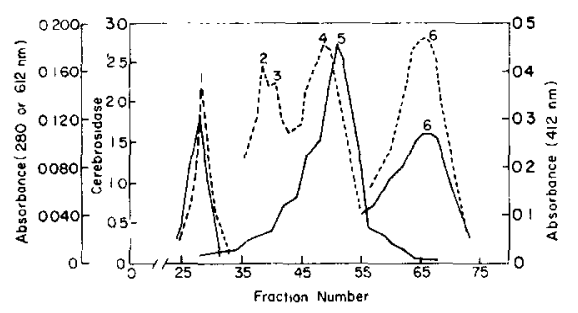

Fig. 2. Gel filtration of cerebroside galactosidase. The column packing $(2.2 \mathrm{~cm} \times 44 \mathrm{~cm})$ was Sepha$\operatorname{dex} \mathrm{G}-200$, equilibrated and eluted with Buffer $\mathrm{B}$ (ref. I) containing 0.I $5 \mathrm{M} \mathrm{KCl}$. Fraction volumes were $2.1 \mathrm{ml}$. For enzyme assay fractions were dialyzed against diluted Buffer A (Table IV). Incubations were carried out as in Table I but with $0.7 \mathrm{ml}$ of enzyme and more concentrated substrate emulsion that contained additionally I. I mg Triton. In Expt. I (dashed line), the applied sample contained I.5 mg of Blue Dextran, $2.25 \mathrm{mg}$ of $\gamma$-globulin, $6 \mathrm{mg}$ of bovine serum albumin (Fraction V), and I.5 mg of cytochrome $c$ (horsc heart). In Expt. 2 (solid linc), thc sample contained $267 \mu \mathrm{g}$ Enzyme I, Blue Dextran, and cytochrome $c$. Peak I is Blue Dextran, measured at 6r 2 nm; Peak 2 is globulin $(280 \mathrm{~nm})$; Peak 3 is probably the dimer ${ }^{27}$ of Peak 4 , albumin (280 nm); Peak 5 is cerebrosidase (nmoles per fraction per $h$ ); Peak 6 is cytochrome $\left(4{ }^{12} \mathrm{~nm}\right)$.

value is similar to that reported for the minor $\beta$-galactosidase of rat kidney ${ }^{28}$, but smaller than that reported for the galactosidase of rat liver (127000) ${ }^{29}$. The recovery of activity in our experiment was low $(25 \%)$, probably because of the long period of time required to carry out the experiment.

\section{Cerebrosidase binding to insoluble materials}

According to the DE DUVE visualization of the lysosome, the act of homogenization releases a certain proportion of the lysosomal enzymes into the cell supernatant fluid. In the case of cerebrosidase, the released enzyme appears to be bound to material of high molecular weight. This was shown by experiments in which the supernatant enzyme solution was passed through columns of Sephadex G-200.

Pig-brain supernatant solution was prepared as previously described ${ }^{4}$ but with an homogenizing medium of $0.15 \mathrm{M} \mathrm{NaCl}$ in $0.02 \mathrm{M}$ potassium phosphate buffer ( $\mathrm{pH}$ 7.4). The solution, after concentration 4-6-fold by ultrafiltration ${ }^{1}$, became slightly turbid and was clarified by centrifugation for $I 65 \mathrm{~min}$ at $55000 \times \mathrm{g}$. When this concentrated solution was passed through a Sephadex G-200 column, the excluded (unretarded) fraction was found to be very turbid and to contain most or all of the applied activity toward ceranide galactuside. From this appearance of insoluble material, one might conclude that its component molecules had been kept in solution by molecules of lower molecular weight, retarded by the Sephadex.

The solubilizing role of the smaller molecules could be played by detergents. This was shown by a series of experiments in which increasing amounts of sodium cholate and Triton X-1oo were added prior to Sephadex chromatography (Expt. I: $0.75 \%$ cholate $+0.1 \%$ Triton; Expt. $2: 2 \%+0.1 \%$; Expt. $3: 6 \%+0.3 \%$ ). In order to prevent separation of detergents from proteins by the gel-filtration phenomenon, the packing and eluting solvents were made up with the appropriate detergent mixture. It was observed that the amount of turbidity decreased and the amount of retarded cerebrosidase increased with increasing detergent concentration. The amount of cerebrosidase activity in the turbid fraction decreased correspondingly: Expts. I, 2, and 3:50, 4I, and 33\%. High-speed centrifugation of the turbid fractions from Expts. 
2 and 3 yielded pellets which contained 23 and $7 \%$ of the recovered enzyme activity. This suggests that at least three molecular forms of cerebrosidase were present, the ratios depending on the detergent concentration: a form small enough to be retarded by the Sephadex, a form large enough to be excluded but stay in suspension on centrifugation, and a highly agglomerated form.

Fig. 3 shows the data from a run similar to Expt. 3. The recoveries of cerebrosidase, nitrophenyl galactosidase, and protein from the column were $9 \mathrm{r}, 64$, and $103 \%$, respectively. The precipitates obtained from the column fractions (see Fig. 3) contained less than $3 \%$ of the protein recovered from the column and no detectable activity toward nitrophenyl galactoside. Of particular interest is the observation that the cerebrosidase of high molecular weight did not appear as a sharp peak, which

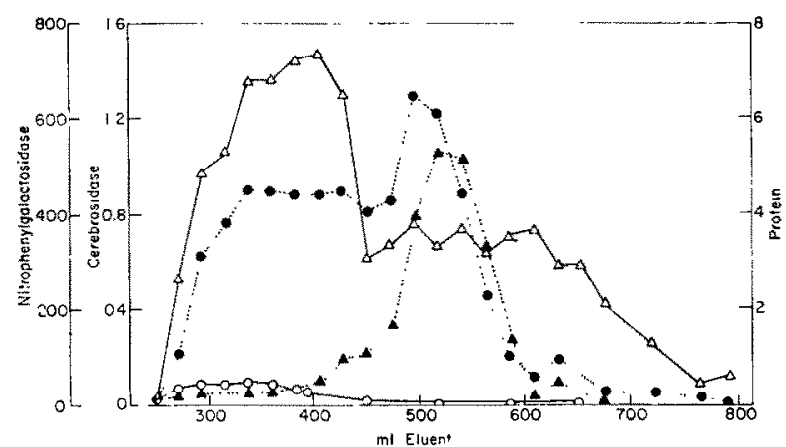

Fig. 3. Gel filtration of the supernatant fluid from pig brain. The column packing $\left(4.75 \mathrm{~cm} \times 4^{8} \mathrm{~cm}\right)$ was Sephadex G-200, equilibrated and cluted with $0.15 \mathrm{M} \mathrm{NaCl}$ in $0.02 \mathrm{M}$ potassium phosphate buffer $(\mathrm{pH} 7.4)$ containing $6 \%$ sodium cholate and $0.3 \%$ Triton $\mathrm{X}-100$. The sample volume was $40 \mathrm{ml}$ (in the same buffer-detergent mixture) and was obtained from $240 \mathrm{ml}$ of supernatant fluid. The fractions $(20-22 \mathrm{ml})$ were centrifuged at $55000 \times \mathrm{g}$ for $165 \mathrm{~min}$. For assay, the precipitates were resuspended in $4 \mathrm{ml}$ of $0.05 \mathrm{M}$ Tris- $\mathrm{HCl}(\mathrm{pH} 7.4)$. The supernatant fractions were dialyzed against the same buffer ( $200 \mathrm{ml} / \mathrm{bag}$ ) with 3 buffer changes over a $4^{8 \text {-h }}$ period. Cerebrosidase was measured as in Table I, with a $4 \mathrm{~h}$ incubation time. $\bullet$, nmoles of mixed cerebrosides hydrolyzed by the supernatant per $h$ per ml fraction; $O$, nmoles of mixed cerebrosides hydrolyzed by the precipitate per h per $\mathrm{ml}$ fraction; $\boldsymbol{\Delta}$, nmoles nitrophenyl galactoside hydrolyzed by the supernatant per $h$ per $m l$ fraction; $\Delta, \mathrm{mg}$ protein in the supernatant per $\mathrm{ml}$ fraction.

indicates that part of the enzyme existed as an assortment of complexes of varying, high molecular weights. Of additional interest is the observation that virtually all the nitrophenyl galactosidase activity was found in the retarded region, and that its molecular weight appears to be a little lower than that of the cerebrosidase.

Similar partial separation into excluded and retarded cerebrosidases was obtained when the particulate enzyme of rat brain was studied. Nerve ending and mitochondrial fractions ${ }^{11}$ from cortex of mature female rats, extracted with $6 \%$ cholate + $0.3 \%$ Triton X-I0o, were found to yield the major part of the activity in the excluded fraction. Comparison of the cerebral cortex with the adjacent white matter from 12 day-old animals yielded the same bimodal distribution.

\section{DISCUSSION}

\section{Subcellular localization}

The evidence now at hand indicates that all the enzymes hydrolyzing sphingolipids are localized in the lysosomes. All require a low $\mathrm{pH}$, occur in particles of inter- 
mediate size, and are greatly activated by cholate or taurocholate (except for cerebroside sulfatase, which was not tested for this effect ${ }^{30}$ ). Moreover, their $K_{m}$ values are moderately similar ${ }^{14,30}$. It is tempting to postulate that all the sphingolipid hydrolases occur in specialized lysosomes which lack the other lysosomal enzymes. There should then be two types of such lysosomes, one (from neurones) acting on the intermediates in ganglioside breakdown, the other (from glial cells) acting on the sphingolipids characteristic of myelin.

\section{Effects of detergents and other lipids}

It is now well known that there are enzymes which are activated by addition of lipids. Some of the enzymes, such as certain electron-transport proteins of mitochondria, act on non-lipids, while others, such as pancreatic lipase and cerebroside galactosidase, act on lipids. In the cases studied in depth, the stimulating effects are seen to depend in a complex manner on salts and $\mathrm{pH}$, and on the nature and concentration of detergent, activator, substrate, and other lipids that might be added. Some effects have been attributed to influences on the intimate structure of the enzyme-lipid complexes that must form, but few explanations have been offered involving possible effects on lipid micelle size and the formation of enzyme-lipid complexes.

It may be postulated that there is an optimal micelle size for lipid substrates and activating lipids. Micelles that are too large may have too little surface area to adsorb to the enzyme efficiently, while micelles that are too small may be too tightly structured to assume the surface form needed for adsorption to the enzyme. The first situation can arise when inert lipids are added to the active lipid without a corresponding increase in concentration of emulsifying agent. This would explain the many inhibitory effects noted for the sphingolipid hydrolases by GATT and ourselves (Table II). Ceramide and palmitic acid could act in this way, while sphingosine may act additionally by forming inactive salts with the bile acid. Thus one cannot state that such effects are specific unless the influence on micelle size is examined, and related lipids are tested similarly.

The inhibitory effects of excessive detergent concentration can be explained as due to formation of excessively small lipid micelles. We noted that high bile salt concentration was inhibitory and that Triton was inhibitory when used with purer enzyme preparations (which contain less lipid and therefore may need less detergent). GATT AND RAPPORT ${ }^{13}$ observed an inhibitory effect of Triton X-IOo on hydrolysis of ceramide lactoside when the concentration of cholate was low. An important conclusion from this hypothesis is that one may have to adjust detergent concentrations to suit the amount and nature of lipid in each system being tested.

The factors that affect the formation of lipid-enzyme complexes have been little studied. It is possible that certain activating lipids (such as bile acids, in the case of lipid hydrolases) exert their effect by forming a ternary complex with the substrate lipid and enzyme. In beginning studies of this phenomenon in our laboratory, we have shown that taurocholate promotes coprecipitation of cerebroside and cerehrosidase. The aggregation process that must precede precipitation would seem to be inimical to intimate contact between enzyme and substrate. However, it may be that the substrate must first be presented to the enzyme molecules in the form of cxcessively small, inert micclles and the two are then induced to aggregate by the bile acid to form active micelles which now contain the enzyme. 
An excellent example of such a situation is seen in the galactosyl transferase which adds a galactose moiety to an acidic bacterial glycolipid ${ }^{31}$. This enzyme requires a neutral lipid (phosphatidyl ethanolamine) and $\mathrm{Mg}^{2+}$ for activity and the mixture of protein and two lipids must coprecipitate for enzyme action to occur.

\section{Comparison with other glycosidases}

An intestinal enzyme has been described ${ }^{26}$ which catalyzes the hydrolysis of ceramide galactoside and glucoside at equal rates at each purification stage. It appears that this enzyme cannot discriminate between the two substrates. Our brain cerebrosidase, on the other hand, was less active toward the glucosyl lipid and this activity could be reduced further by acid precipitation. Our enzyme was markedly inhibited by galactose, galactonolactone, and related compounds, but not by glucose and its corresponding compounds. The specificity of glycosidases can apparently be established by such comparisons ${ }^{24,32-34}$. It therefore appears that the brain enzyme is specific for the galactosyl lipid and that a separate ceramide glucosidase exists in brain. Incidentally, the inhibitory effect of galactonolactone is not due to formation of a covalent bond with an amino acid near the enzyme's active center, for dialysis overnight restored much of the activity.

Our cerebroside galactosidase was found to be approximately as active toward ceramide lactoside. Also (Expt. 3, Table II) we found that added lactoside inhibited hydrolysis of cerebroside. These observations could be construed to mean that a single enzyme acts on both substrates. However, GATT AND RAPPORT ${ }^{13}$ have isolated a galactosidase from rat brain which hydrolyzes lactoside, but not cerebroside. It is therefore likely that the inhibitory effect of lactoside was due to competitive attachment to the active enzyme site without its being a substrate, as well as to simple dilution of the substrate in its micelle.

Our preparation was rather inert toward ceramide trihexoside but the GATTRAPPORT galactosidase was much more active toward the trihexoside than the dihexoside $^{35}$. From this one might conclude that their preparation contained a trihexosidase together with dihexosidase, while ours contained the dihexosidase and monogalactosidase. A purer trihexosidase has been obtained from intestine, free from activity toward the di- and monohexosides ${ }^{30}$.

It is thus likely that there are at least three different galactosidases acting on different galactolipids in brain. All of these appear to be active toward the unnatural substrate, nitrophenyl galactoside. Assay of rat brain lysosome-rich particles gave a ratio of over 80 for nitrophenyl galactosidase/cerebrosidase, while the ratio with purified cerebrosidase was 2 . It is very likely that most of the activity observed with the unnatural substrate does not represent activity toward glycolipids but rather activity toward other galactosides occurring in brain. The finding that nitrophenyl galactosidase activity is normal in the brains of cases with Krabbe disease ${ }^{37}$ thus may not bear on the observation that cerebroside deposits can be observed in this disorder $^{38}$.

\section{ACKNOWLEDGMENTS}

This work was supported in part by Research Grant NB-03Ig2 from the National Institutes of Health, U.S. Public Health Service, and PHS Training Grant 
No. 74I7 from the National Institute of Mental Health. We are greatly indebted to Dr. Otto Z. Sellinger for his advice in the preparation of the lysosome-rich preparations and the assays of glucosaminidase and aryl sulfatase. The antibiotics were gifts from The Upjohn Company, Kalamazoo, through the courtesy of Dr. JoHN T. CoRrell. The excellent technical assistance of Carolyn Seide, Dolores Blacirmer, and SUSAN BowEn is appreciated.

\section{REFERENCES}

I D. M. Bowen and N. S. Radin, Biochim. Biophys. Acta, I52 (1968) 587 .

2 O. Z. Sellinger and R. A. Hiatt, Brain Res., 7 (Ig68) igi.

3 O. Z. Sellinger, G. D. Rucker and F. De Balbian Verster, J. Neurochem., i (I964) 27 I.

4 A. K. HajRa, D. M. Bowen, Y. Kishimoto and N. S. Radin, J. Lipid Res., 7 (ig66) 379.

5 N. S. Radin AND Y. AKahori, J. Lipid Res., 2 (I96I) 335.

6 T. Taketomi and T. Yamakawa, J. Biochem. Tokyo, 54 (I963) 444.

7 H. E. Carter, O. Nalbandov and P. A. Tavormina, J. Biol. Chem., I92 (1951) 197.

8 H. E. Carter, J. A. Rothfus and R. GigG, J. Lipid Res., 2 (I96I) 228.

9 K. C. Kopaczyk and N. S. Radin, J. Lipid Res., 6 (I965) I40.

io O. Z. Sellinger and F. De Baldian Verster, J. Biol. Chem., 237 (I962) 2836.

i I M. Kurokawa, T. Sakamoto and M. Kato, Biochim. Biophys. Acta, 94 (1965) 307.

I 2 O. Z. Sellinger and G. D. Rucker, Life Sci., 3 (I964) I097.

I 3 S. Gatt and M. M. Rapport, Biochem. J., toi (I966) 680.

I 4 S. GatT, in S. M. Aronson AND B. W. Volk, Inborn Disorders of Sphingolipid Metabolism, Pergamon, Oxford, I967, p. 261.

I5 S. Gat, J. Biol. Chem., 24 I (1966) 374.

I6 M. V. Kelemen and W. J. Whelan, Arch. Biochem. Biophys, II 7 (1966) 423.

I 7 J. C. CAYGILL, Biochem. J., 98 (Ig66) 8P.

I 8 W. Schroeder, B. Bannister and H. Hoeksema, J. Am. Chem. Soc., 89 (I967) $244^{8}$.

19 H. Hoeksema, J. Am. Chem. Soc., 86 (1964) 4224.

20 J. Folch, M. I.f.es ann G. H. Slonane-Stanley, J. Biol. Chem., 26 (1957) 497.

2 I Y. Kishimoto and N. S. Radin, J. Lipid Res., 6 (1965) 435.

22 N. S. Radin, J. Chromatog., 20 (I965) 392.

23 K. Sambasivarao and R. H. MCCluer, J. Lipid Res., 4 (1963) Io6.

24 S. Gat' and M. M. Rapport, Biochim. Biophys. Acta, i I3 (I966) 567.

25 C. C. Sweeley and B. Klionsky, J. Biol. Chem., 238 (I963) PC 3 I $_{4} 8$.

26 R. O. Brady, A. E. Gal, J. N. Kanfer and R. M. Bradley, J. Biol. Chem., 240 (I965) 3766. 27 P. ANDrEws, Biochem. J., 96 (I965) 595.

28 D. Kobinson, R. G. Price and N. Dance, Biochem. J., Ioz (1967) 525.

29 F. Chytil, Biochem. Biophys. Res. Commun., I9 (1965) 630.

3o E. Mehl and H. Jatzkewitz, Z. Physiol. Chem., 339 (I964) 260.

3 I L. Rothfield, M. Takeshita, M. Pearlman and R. W. Horne, Federation Proc, 25 (I966) 1495 .

32 J. Conchie and G. A. Levvy, Biochem. J., 65 (1957) 389.

33 G. A. Levvy, A. McAldan And A. J. HAy, Biochem. J., 82 (1962) 225.

34 R. G. Price. and I. Rorinson, Comp. Rinchem. Physinl., 7 (1966) 1ng.

35 S. Gatt, Biochim. Biophys. Acta, I 37 (1967) I92.

36 R. O. Brady, A. E. Gal, R. M. Bradley and E. Martensson, J. Biol. Chem., 242 (I967) Io21. 37 J. Austin, D. Armstrong and L. Shearer, Arch. Neurol., I3 (1965) 593.

38 J. H. Austin, J. Neurochem., Io (1963) 921 .

Biochim. Biophys. Acta, I 52 (1968) 599-610 